\title{
"The improvement of management of social and labor relations as one of the directions of economic development"
}

\begin{tabular}{|c|c|}
\hline AUTHORS & Hanna Mykhalchenko iD https://orcid.org/0000-0003-2616-9499 \\
\hline ARTICLE INFO & $\begin{array}{l}\text { Hanna Mykhalchenko (2018). The improvement of management of social and } \\
\text { labor relations as one of the directions of economic development. Social and } \\
\text { labour relations: theory and practice, } 8(2), 56-68 \text {. doi:10.21511/slrtp.8(2).2018.06 }\end{array}$ \\
\hline DOI & http://dx.doi.org/10.21511/slrtp.8(2).2018.06 \\
\hline RELEASED ON & Thursday, 14 March 2019 \\
\hline RECEIVED ON & Tuesday, 30 October 2018 \\
\hline \multirow[t]{2}{*}{ ACCEPTED ON } & Friday, 28 December 2018 \\
\hline & $(c))_{\text {EY }}$ \\
\hline LICENSE & $\begin{array}{l}\text { This work is licensed under a Creative Commons Attribution } 4.0 \text { International } \\
\text { License }\end{array}$ \\
\hline JOURNAL & "Social and labour relations: theory and practice" \\
\hline ISSN PRINT & $2410-4752$ \\
\hline ISSN ONLINE & $2415-3389$ \\
\hline PUBLISHER & LLC "Consulting Publishing Company "Business Perspectives" \\
\hline FOUNDER & $\begin{array}{l}\text { State Higher Educational Establishment "Kyiv National Economic University } \\
\text { named after Vadym Hetman", Social and Labour Relations Institute }\end{array}$ \\
\hline
\end{tabular}

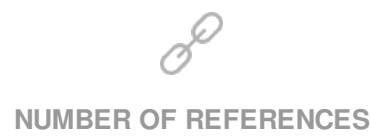

38

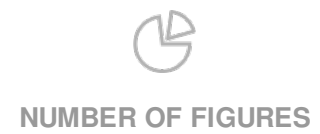

3
NUMBER OF TABLES

2

(C) The author(s) 2023. This publication is an open access article. 


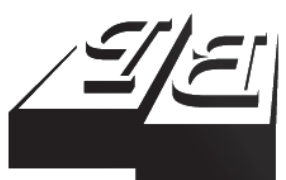

BUSINESS PERSPECTIVES

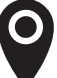

Publisher:

LLC "CPC "Business Perspectives" Hryhorii Skovoroda lane, 10, Sumy, 40022, Ukraine www.businessperspectives.org

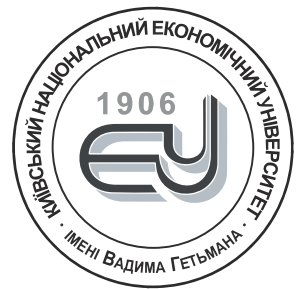

\section{HETMAN KNEU}

Founder:

State Higher Educational Establishment "Kyiv National Economic University named after Vadym Hetman",

Prospect Peremogy, 54/1

Kyiv, 03057, Ukraine

https://kneu.edu.ua/

\title{
THE IMPROVEMENT OF MANAGEMENT OF SOCIAL AND LABOR RELATIONS AS ONE OF THE DIRECTIONS OF ECONOMIC DEVELOPMENT
}

\begin{abstract}
The article deals with the main problems in management of social and labor relations, which are vital for economic development. The relevance of the research in accordance with the attempts of Ukraine to get closer to European standards of quality of life while minimize existing demographic problems, increasing inequality, impoverishment of the population, deterioration in the quality of labor resources is proved.

The purpose of the research is to identify the main problems of social and labor relations related to employment of the population and to justify ways to improve their management and determine practical recommendations for the implementation of effective economic and social policies in this direction.

In order to provide solutions to scientific problems general scientific methods are used in the research They allow determining the state of employment of the population, its dynamics, compliance with the minimum wage in Ukraine, as one of the main standards, guaranteed by the state, similar to the standards adopted in the European Union; also perform comparisons of the average wage in Ukraine with other countries. Taking into account significant migration trends, the causes, characteristics and consequences of internal and external migrations for the socio-economic development of the country are analyzed. As a result, it is proved that for the regulation of the labor market a general improvement in the economic situation and capital investment activity is needed, which will allow increasing in the number of jobs and labor requirements. Thus, the main task of effective regulation of the social and labor sphere should be the creation of satisfactory economic conditions for the sustainable and expanded reproduction of the total labor force in accordance with the needs of the country and its regions.

According to the results of the research, the measures to improve the system of state and regional regulation of social and labor relations, which would correspond to existing market relations, sustainable economic development of the country and take into account the economic interests of all participants in social and labor relations in society, are proposed.
\end{abstract}

Keywords

JEL Classification

Г.Г. Михальченко (Україна)

\section{(1) (1)}

This is an Open Access article, distributed under the terms of the Creative Commons Attribution 4.0 International license, which permits unrestricted re-use, distribution, and reproduction in any medium, provided the original work is properly cited. social and labor relations, minimum wage, average wage, employment, migration processes

E24, H75, J21, O15
Hanna Mykhalchenko, Doctor of Economic Sciences, Ph.D., fessor, the Head of Department of Economy of Enterprises and Management, Engineering Pedagogic Academy, Ukraine.

\section{УДОСКОНАЛЕННЯ УПРАВЛІННЯ ПРОБЛЕМАМИ СОЦІАЛЬНО-ТРУДОВИХ ВІДНОСИН ЯК ОДНОГО ІЗ НАПРЯМІВ РОЗВИТКУ ЕКОНОМІКИ}

\section{Анотація}

В статті розглянуто основні проблеми управління соціально-трудовими відносинами, які є нагальними для розвитку економіки. Автором доведено актуальність дослідження відповідно до намагань України наблизитися до європейських стандартів якості життя та мінімізувати існуючи демографічні проблеми, посилення нерівності, зубожіння населення, погіршення якості трудових ресурсів тощо.

Метою дослідження було визначення основних проблем соціально-трудових відносин, пов'язаних із зайнятістю населення та обгрунтування напрямів удосконалення їх управлінням та визначення практичних рекомендацій щодо реалізації ефективної економічної і соціальної політики в цьому напрямку. 
В дослідженні використовувалися загально наукові методи для забезпечення вирішення поставлених наукових завдань, які дозволили визначити стан зайнятості населення, його динаміку, відповідність мінімальної заробітної плати в Україні, як одного з головних стандартів, що гарантується державою, аналогічним стандартам, прийнятим в Свропейському Союзі; також виконати порівняння рівня середньої заробітної плати в Україні з іншими країнами. Враховуючи значні міграційні тенденції, проаналізовано причини, особливості та наслідки внутрішніх та зовнішніх міграцій для соціально-економічного розвитку країни. В результаті, доведено, що для регулювання ринку праці необхідне загальне покращання економічної ситуації та інвестиційної активності капіталу, що дозволить збільшити кількість робочих місць та потребу в робочій силі. Таким чином, основним завданням ефективного регулювання соціально-трудової сфери повинно стати створення задовільних економічних умов для сталого і розширеного відтворення сукупної робочої сили відповідно до потреб країни та їі регіонів.

За результатами дослідження автором запропоновано комплекс заходів щодо удосконалення системи державного та регіонального регулювання соціально-трудових відносин, що відповідала б існуючим ринковим відносинам, сталому економічному розвитку країни та враховувала економічні інтереси всіх учасників соціально-трудових відносин у суспільстві.

Ключові слова соціально-трудові відносини, мінімальна оплата праці, середня оплата праці, зайнятість, міграційні процеси

Класифікація JEL E24, H75, J21, O15

\section{INTRODUCTION}

In a market economy, the problem of social and labor relations, the efficiency of the functioning of the labor market, employment of the population determine the quality of life of society, the comprehensiveness of development and self-realization of the individual. Employment of the population is an important factor in the development of the socio-economic system, necessary condition for its reproduction and life-activities. The crisis situation in the country's economy has changed the main parameters of the labor market and reflected the need for systematic advance work towards vocational training, addressing the current and future needs of employers in the staff, the necessary qualifications, the deepening of links between the labor market and the market for educational services. Consequently, the modern economic environment requires new approaches to the solution of the problem of unemployment and the regulation of the labor market.

\section{LITERATURE REVIEW}

The actuality of the issues studied in accordance with the problems of social and labor relations as one of the important directions of economic development, the functioning of the modern labor market as a determining factor of the quality of life of the population is evident in the considerable interest in this problem, both by Ukrainian and foreign scientists. Many economists have repeatedly attempted to characterize the features of social and labor relations that exist in modern society. For example, Bliznyuk, Godin, Grishnova, Vasilenko, Brych, Zayets, Koretsky, Libanova, Osovska, Petyukh and others. But this problem requires a profound scientific study in a comprehensive theoretical analysis and the development of practical recommendations on this basis that could be used to develop and implement effective economic and social policies aimed at developing the European standards of life on its way to full membership in the European Union.

In the scientific literature, the problems of labor market are constantly focused. At the same time, there is no single conceptual apparatus in this direction of study nowadays. So, in researches of Osovska (2010) the labor market is regarded as a system of exchange of individual abilities to work on the fund of vital values necessary for the recruitment of labor and considers it economically accepted and equivalent to the use of two terminological phrases - "the market of labor force" and "the labor market", since they are closely interconnected and mutually supplemented (Osovska, \& Krushelnytska, 2010).

The labor market, according to research of Petiukh (1999), is a socio-economic category, that characterizes the relations of people, that are manifested in the process of hiring, evaluating, and dismissing the workers and setting the amount of compensation for the labor employed depending on a number of factors, and employment is the object of regulation of the labor market.

Libanova (2004) examines the labor market from the standpoint of the Institute for the interaction of labor force consumers, that is, employers (legal entities and individuals on the one hand and specific individuals with certain 
physical and mental abilities, certain professional knowledge, skills and abilities on the other); stressing that labor employment is a major indicator of the balance of the labor market.

In turn, Brych (2003) argues, that the labor market is a system of labor relations, those reflects the level of social development and achieved a balance of interests between the subjects involved in the labor market: employers, workers, the state, trade unions and intermediaries.

Kachan (2008) considers that the labor market is a system of economic relations, in which demand and supply are formed, and the price of labor is established.

Consequently, most researchers consider the notions of the labor market and employment as identical and interconnected. However, Minenko (2010) draws attention to the methodological difficulties that arise when considering the nature of the regulation of the labor market and employment, which may vary with the expanded or narrowed treatment of the labor market. Thus, Hrishnova (2009) emphasizes that the labor market is not limited to unemployment-job relations and the filling of vacancies, but covers the entire sphere of social and labor relations, including hired labor. This provision has not only theoretical but also important practical significance, since it follows from this that the object of the labor market policy should be a broad circle of labor relations and all economically active population, the problems of payment and working conditions, the volume and intensity of the performed work, stabilization and employment guarantees, labor motivation, training and retraining of the work force.

Regarding the statistical information on the volume of unemployment, there are two main sources in Ukraine. The first source is the administrative data of the State employment service on the number of unemployed persons who were in its registration, that is, the number of registered unemployed. In accordance with the Law of Ukraine "On employment of the population", the able-bodied citizens of working age who, because of the absence of work, do not have earnings or other income envisaged by the legislation and are registered with the State Employment Service as seeking work, are ready and able to start suitable work, are recognized as unemployed (Vidomosti Verkhovnoi Rady Ukrainy, 2013). The second source is the information of sample surveys of households and citit zens, but in Ukraine, the All-Ukrainian Population Census was held only in 2001. Its next transfer is scheduled for 2020. Thus, the modern labor market is completely unpredictable, and without analyzing the scope of informal employment, wages, and social insurance, it is impossible to build an effective economic and social policy of the state that will ensure decent living for its citizens.

\section{THE AIMS}

The aim of the study is to identify the main problems of social and labor relations related to the employment of the population and to justify the directions of improvement of their management and to determine practical recommendations for implementing an effective economic and social policy in this direction.

\section{METHODS}

In the research the following methods are used: generalization and systematization for the definition of existing theoretical approaches to the study of social and labor relations, the market of labor, employment, migration processes; sociological, statistical, generalization and grouping - in the process of identifying the effects of poverty, unemployment, labor migration; statistical, graphic - in determining the approaches to the construction of tables, charts, diagrams to ensure the solution of the scientific research objectives.

\section{RESULTS}

In 2017 the Government of Ukraine presented the National Report "Sustainable development goals: Ukraine", which defines the basic indicators for achieving the goals of sustainable development (CSR). The report presents the results of the adaptation of 17 global CSRs, taking into account the specifics of national development. Each 
global objective has been revised, taking into account the specifics of national development. Based on this, four national and ten regional public consultations were held to identify development priorities for each goal. The inclusive process of determining the tasks of the Central Bank took place in several areas, the main of which: fair social development; sustainable economic growth and employment; effective management; ecological equilibrium etc. (Ministerstvo ekonomichnoho rozvytku i torhivli Ukrainy, 2017).

Today in Ukraine new strategic goals of the state development are defined, the achievement of which in the conditions of a decline in production and deterioration of the financial condition of enterprises, the growth of the dynamics of migration processes, as well as the receipt of Ukraine visa-free regime with the European Union (EU), has become more complicated. Thus, the implementation of the Ukraine-2020 Sustainable development strategy, the Medium-term plan of government priority actions by 2020, the requirements of the Association Agreement between Ukraine and the EU should ensure an increase in the quality of life in Ukraine, the withdrawal of the state in the leading positions in the world and the subsequent entry into The EU as a full member of it.

To accomplish these tasks, the creation of economic conditions for sustainable development necessitates, first of all, the expanded reproduction of the total labor force at a qualitatively new level, which envisages the possibility of meeting the needs of the population of the region in employment, a decent level of material security, obtaining educational and professional knowledge, the availability of social protection system in the case of involuntary unemployment.

The employment market is an integral part of the country's economic system, since it reflects most of the political and socio-economic processes taking place in the state. Achieving a high level of employment is one of the main goals of the macroeconomic policy of the state. It is common knowledge, that lower unemployment also causes a decrease in the level of poverty in the country. According to the Ministry of Finance of Ukraine, the unemployment rate in 2017 amounted to almost 10\%, therefore problems of impoverishment of the population are deepened (Figure 1).

Among the economic conditions for the effective functioning of the labor market, one of the most important factors of social and labor relations is the level of wages of full-time employees.

In 2017 the minimum wage was doubled to UAH 3.200. This ensured the growth of labor income for almost 4 mln low-paid workers, but, on the other hand, the introduction of legislative changes in the structure of minimum wages (including additional payments and surcharges) and the abandonment of the minimum wage guarantees (labor remuneration and discharge rates) at the level the artificially low living wage led to the devaluation of skilled labor and alleviated the expected positive effect of raising the minimum wage in terms of rising labor income (Federatsiia profesiinykh spilok Ukrainy, 2018). At the same time, it also significantly influenced the development of the economy and did not lead to the creation of new work positions and jobs.

Today the Ukrainian minimum wage is UAH 3.723, which is approximately USD 4.5 a day. In accordance with

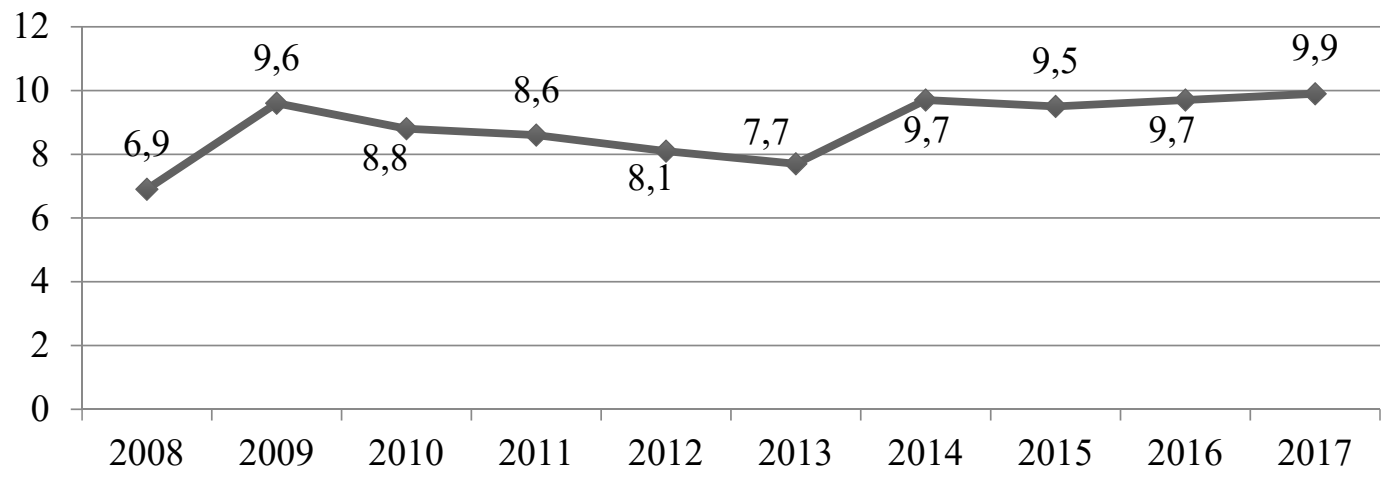

Figure 1. The unemployment rate in Ukraine for 2008-2017 
the UN standards to live on only one minimum wage or pension means living below the poverty line. The size of the minimum wage is close to Ukrainian only in Bulgaria, but there it is twice higher than in Ukraine (Figure 2). In turn, the International Labor Organization and members of the European Parliament believe that the minimum wage should be at least $60 \%$ of the average monthly salary.

In the structure of incomes the share of wages is only $40 \%$, which is due to an extremely low share of wages in the cost of production (in Ukraine it is 6-12\%, however, in the USA and Europe, this figure is on average not less than $40 \%)$.

It should be noted that today a significant part of the Ukrainian population lives below the poverty line. At the same time, the average wage in August 2018 amounted to UAH 8.977 or approximately EUR 275, and in European countries this indicator varies between EUR 3.000-4.000 (Zhabin, Isakova, \& Skorokhod, 2018) while the salaries of secondary workers are much higher (Figure 3). Thus, in Ukraine it is 3-19 times lower than in the European Union.

The ILO Decent work program for Ukraine for 2016-2019 does not establish national standards and norms of dignity, but only sets the positive directions for changes in social policy, that will contribute to the growth of the dignity of labor. Attention is paid to raising the minimum and the average wage, reducing wage arrears.

In addition, the tendency of saving on wages both from employers and from the state during the crisis intensified, which led to massive impoverishment of workers. In 2013 Ukraine was among the countries with the lowest average incomes per adult population, and by this time it is dubious leadership (RBK-Ukraina, 2017).

At the same time, the inequality of labor income of Ukrainian workers is increasing. Today the average wage of $1 \%$ of the highest paid Ukrainian workers surpasses the average earnings of $50 \%$ of the least-paid workers by 43.3 times, while this indicator in the Scandinavian countries is equal to 7.1, in European countries - 11.7, in USA - 24 times. The ratio of official salaries between the main occupation employee and the manager at individual enterprises, including public ones, reaches 1:200, the inter-sectored relationship between the highest and lowest salaries has increased from 5.55 in 2013 to 8.83 times in 2017, and the pay gap in wages is almost 25\% (Chyrva, 2016).

In general we can observe an increase in the imbalance of forces between workers and robots, which creates a disruptive economic model, in which the concentration of wealth leads to an extraordinary inequality of people.

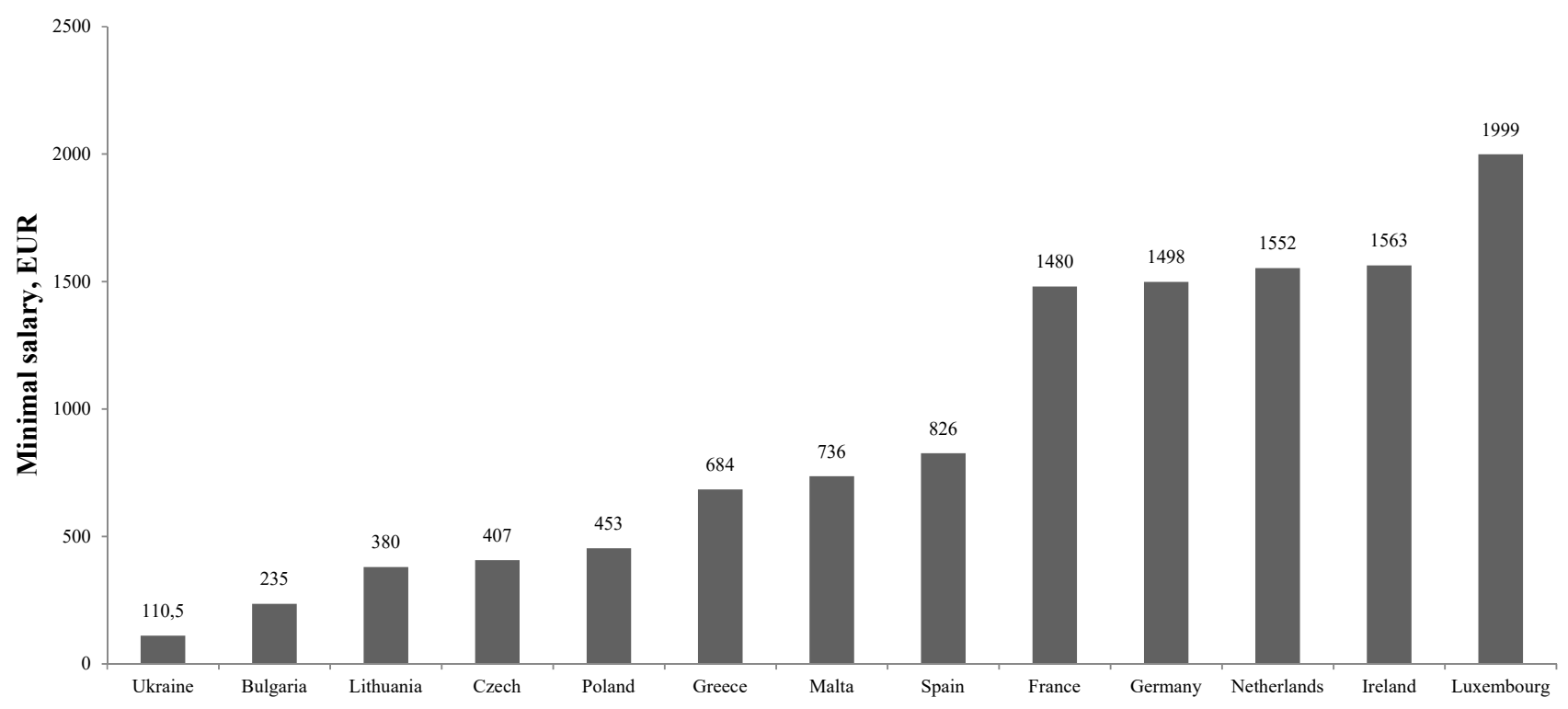

Figure 2. Minimum wage in some European countries, EUR 


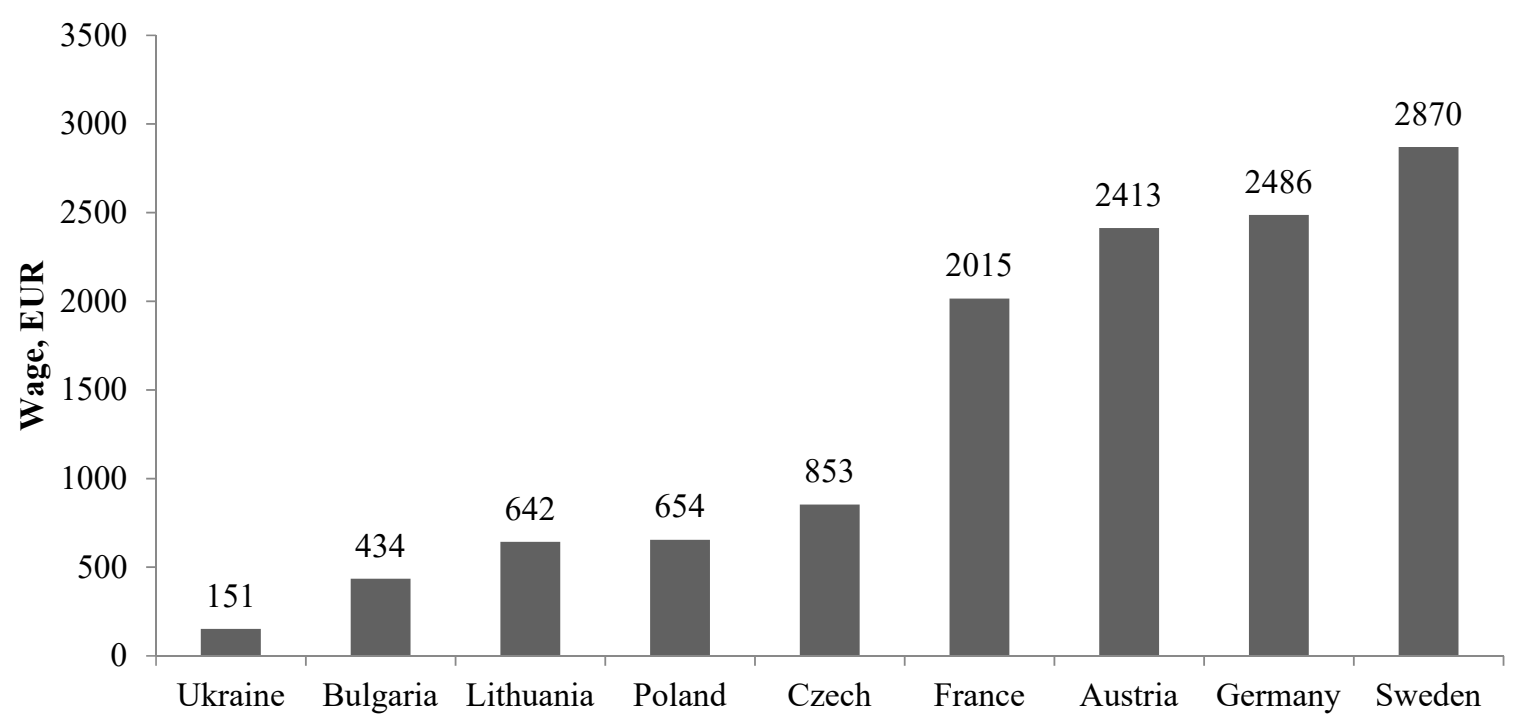

Figure 3. Wages of the average qualification workers in August 2017, EUR

Source: Built according to (Wagelndicator, 2018).

A total of $1 \%$ of the earth's population controls all the wealth of the world, and $80 \%$ of all profits in the world are owned by $10 \%$ of companies; only $60 \%$ of employees have formal labor contracts, and most of them are not guaranteed, and $40 \%$ of workers are deprived of minimum wages and social protection (Federatsiia profesiinykh spilok Ukrainy, 2017).

It should be noted, that Ukraine has become one of the poorest countries in the world in terms of living standards and ranked the 7 th place in the international poverty rating of countries, that annually publishes Bloomberg, and according to the ranking of the level of happiness the population is the 132nd among 155 countries, about $60 \%$ of Ukrainians live below the poverty line (Glavcom, 2017).

The size of the main state standards and guarantees - the subsistence minimum, the minimum wage and the minimum age pension is more than twice lower than it should be under the current legislation. Thus, inequality is increasing in Ukraine, which contradicts Art. 48 of the Constitution of Ukraine, respectively, which citizens of Ukraine have the right to an adequate standard of living for themselves and their families (Verkhovna Rada Ukrainy, 1996). It should be noted, that the eradication of inequality and injustice and poverty alleviation are priorities among the 17 sustainable development goals, that are applied to the whole world, both for the rich and the poor, in accordance with the new program "Transforming our World: An Agenda for Sustainable Development to 2030 ".

But in Ukraine by this time the average welfare level of the population remains extremely low, based on an analysis of its main indicators (Table 1).

Table 1. The dynamics of basic social standards and guarantees in Ukraine, UAH

\begin{tabular}{l|c|c|c|c|c|c|c|c}
\hline \multicolumn{1}{|c|}{ Indicator } & $\mathbf{2 0 1 0}$ & $\mathbf{2 0 1 1}$ & $\mathbf{2 0 1 2}$ & $\mathbf{2 0 1 3}$ & $\mathbf{2 0 1 4}$ & $\mathbf{2 0 1 5}$ & $\mathbf{2 0 1 6}$ & $\mathbf{2 0 1 7}$ \\
\hline $\begin{array}{l}\text { Average annual living wage (average } \\
\text { per person per month, UAH) }\end{array}$ & 843.2 & 914.1 & $1,042.4$ & $1,113.7$ & $1,176.0$ & $1,227.3$ & $1,388.1$ & $1,603.7$ \\
\hline $\begin{array}{l}\text { The average monthly salary } \\
\text { Minimum pension }\end{array}$ & 2.239 & 2.633 & 3.000 & 3.274 & 3.470 & 4.207 & 5.5183 & 7.601 \\
\hline
\end{tabular}

It should be noted that with the growth of the average monthly salary there was a decrease in real wages, and the increase in the amount of arrears of wages increased more than 2 times (Table 2). All this happens against the backdrop of rising consumer prices, rising tariffs, which in recent years have increased by 5,7 people have gas for 
the population, 11 times for heating, and only 2.8 times for the heating, and the debt for you paid salaries reached an amount of 2.7 bln UAH (State statistics service of Ukraine, 2018; Federatsiia profesiinykh spilok Ukrainy, 2018; Ministry of social policy, 2017).

Table 2. The dynamics of indebtedness with types of wages by types of enterprises for 2012-2017, mln

Source: Built according to (State statistics service of Ukraine, 2018; Federatsiia profesiinykh spilok Ukrainy, 2018; Ministry of social policy, 2017).

\begin{tabular}{|c|c|c|c|c|c|c|}
\hline Type of enterprise & 2012 & 2013 & 2014 & 2015 & 2016 & 2017 \\
\hline Total & 913.8 & 830.1 & 753.0 & $1,320.0$ & $1,881.0$ & $1,791.0$ \\
\hline \multicolumn{7}{|l|}{ Including: } \\
\hline economically active enterprises & 404.1 & 419.0 & 413.1 & $1,302.7$ & $1,118.2$ & $1,456.8$ \\
\hline enterprise bankrupt & 461.9 & 361.4 & 306.3 & 546.3 & 633.8 & 730.0 \\
\hline economically inactive & 47.8 & 49.7 & 33.6 & 31.8 & 38.9 & 394.8 \\
\hline
\end{tabular}

Also, a significant labor market problem is the lack of a transparent system of legal regulation and employment regulation due to the large shadowing of this process. The problems of illegal employment relations are related to insufficient control over the observance of the norms of the labor legislation in terms of the proper execution of employers' employment claims, the desire of the business to receive extra profits through the use of cheap labor and the extremely high tax pressure on employers, which leads to spreading the practice of remuneration in "envelopes".

Wage increases in Ukraine are crucial to maintaining the standard of living, but an increase that will not be justified by economic development in the country will cause ambiguous consequences, as the country does not have an adequate level of economic growth for today's conditions, and inflationary processes will not allow to provide a protracted growth of wages in comparison with the growth of consumer prices. On the other hand, the result of an increase in the minimum wage is the increase in unemployment, as employers are trying to reduce costs proportionally by reducing the number of employees. In this case, the so-called part-time employment is gaining popularity, when workers will officially work part-time, and in reality fulfill the same duties.

Experts from the American National Bureau of Economic Research have studied the experience of 14 countries in detail and concluded that raising the minimum wage by only USD 4-5 would result in job losses in the enterprise by $2 \%$ (Profspilkovi visti, 2018), that is, real wage increases are possible only for conditions of general economic growth.

Particularly complex situation is in social and labor relations among young people. A quarter of the young Ukrainians do not have a job. Unemployment among young people is the highest in Europe. The insufficient level of state guarantees for the provision of the first job, the inadequacy of the level and quality of the education received by the current professional requirements, the lack of practical experience, unreasonably overly-charged youth demands and their non-compliance with employers' proposals intensify labor market tensions and result in youth unemployment. It is worth noting that some young people have a desire to have high pay at once with minimal effort.

The underlying problem of employment is hidden unemployment. Almost a quarter of the population of Ukraine ( $22.3 \%$ or $3.5 \mathrm{mln}$ people) is compelled to accept the proposals of unscrupulous employers and work semi-legally or illegally (Overchuk, 2018).

Consequently, the spread of illegal employment relations is due to insufficient co-supervision of compliance with the norms of labor legislation in terms of the proper formalization of labor relations by the employer; a significant level of financial burden on the wage fund; unregulated internal labor migration, the main factors of which are the imbalance of demand and supply of labor across the regions of the country.

There is no doubt, that the deterioration in the level of economic development of the country and the material well-being of citizens significantly affects the health of the population, which also worsens the quality of the country's labor resources. Poor sections of the population suffer from lack of access to the necessary medical care. 
Ukraine was among the 36 countries with a catastrophic personal expense for citizens (more than 25\% of household income) (World health organization, 2016).

At the same time, most Ukrainians are under the influence of serious risk factors (smoking, excessive alcohol consumption, malnutrition, lack of physical activity, air and water pollution) and do not receive effective and qualitative assistance at the level of civilized countries. In addition, our citizens remain vulnerable to financial impoverishment in the event of illness, despite the fact that Ukraine spends a significant amount of its medical budget (Apteka, 2014).

Today, only a limited number of countries can provide their population with medical assistance in full, exclusively on a budget basis. The solution to these issues depends largely on the health care system, which now faces a difficult and not very effective reformation in the country. Today, the legislation of Ukraine provides for the provision of a health care system with budget expenditures of not less than $10 \%$ of the national income, and for the 11 years of the existence of the relevant Law, this norm has never been implemented (Mykhalchenko, \& Kobylianskyi, 2017). The state budget provides Ukrainian medicine only partially (3-5\%), the other part is actually paid by citizens independently, buying medicines and medical services. Today, Ukraine ranks last in terms of the amount of money spent by the state on a budget per patient per year - USD 149. But in Germany there are four times fewer hospitals than in Ukraine, and costs for each patient are 20 times higher. The duration of stationary, the most expensive treatment, in our country is 50\% longer compared to the EU countries (Myskevych, 2012).

The maintenance of the health of the working population for Ukraine is a prerequisite for the preservation of its labor potential, but along with demographic problems, you are also worried about working conditions at the enterprises of the country. In conditions of market relations in the struggle to increase the profit of employers and owners, on the one hand, and the weakening of state control in the field of working conditions on the other, the number of violations of workers' rights to safe and healthy working conditions, benefits and compensation for harmful working conditions increases, there are cases of concealment of injuries and occupational diseases. The results of state sanitary and epidemiological surveillance of working conditions in 2015 for 66.725 industrial facilities show that only $29.7 \%$ (2014 - 31.5\%, $2013-31.1 \%)$ of they meet the requirements of the sanitary legislation and $27.8 \%$ (2014 - 24.7\%, $2013-24.4 \%)$ of the facilities, not complying with the current sanitary-and-hygienic standards (Shafranskyi, 2016). Today, with the destruction of the nation's sanitary and epidemiological service, the situation is only aggravated. In general, such a critical situation is conditioned by economic problems (obsolete technologies and equipment, lack of incentives for employers to provide safe working conditions, reducing investment etc.) and social problems (lack of job-seekers' care, poor quality of medical services, incorrect priorities in the attitude of employees to their own safety in the workplace etc.).

Thus, the non-solution of the problem of low level of labor income in the conditions of Ukraine's accession to the European Union provokes a further decline in the living standards of the working population, the actual absence of the middle class, the lack of decent jobs, the growth of informal, shadow employment and the external labor migration of skilled workers.

In turn, insufficient number of jobs, low wages, and non-conforming working conditions lead to increased labor migration both within Ukraine and abroad. One of the migration trends in Ukraine is the process of urbanization: more than $2.3 \mathrm{mln}$ people with a permanent place of registration and residence in rural areas work in Kyiv, regional centers, cities and other centers of economic activity, which form "development areas". Along with this, the trend of urbanization and localization of regional development has a reverse effect on migration processes. Today, according to various estimates, $2.5 \mathrm{mln}$ to $6.5 \mathrm{mln}$ of our citizens work abroad (Federatsiia profesiinykh spilok Ukrainy, 2018). The main reasons for this are political instability and dangerous situation in the country, lack of sufficient number of jobs, low wages, high inflation, lower living standards, and increased levels of criminality. Almost three out of five Ukrainians do not see their future in Ukraine. Every second citizen is not satisfied with the size of the salary and the level of economic development. Thirty less than half of them consider it impossible to remain in a country where corruption is not respected and corruption flourishes (Chyrva, 2016). According to the State Statistics Service of Ukraine in 2015-2017, 1.303 thousand citizens of Ukraine stayed abroad for work, which is 100 thousand more than in 2010-2012 (State statistics service of Ukraine). According to the World Ukrainian 
Forum, the actual scope of external labor migration reaches $7 \mathrm{mln}$. So, as we see the various data, we are led to a disappointing conclusion about the significant migration outflow of the population of Ukraine.

A significant problem for any country is the flushing out of the intellectual part of the population as a result of the migration processes.

According to experts, in 90's Ukraine lost $15-20 \%$ of its intellectual potential as a result of emigration and the transfer of specialists to work, that did not require professional work and professional knowledge. Beginning in 2009 , the volume of "outflow of intelligence" is again increasing. The emigration of scientists contributes to the fact that developed countries are interested in "importing intelligence". In countries that are technological leaders (USA, Germany), special regulations are introduced in the emigration rules to attract scholars. Thus, for today Ukraine continues to be a donor country of highly skilled specialists and reduces the quality of its human capital.

An essential feature of Ukrainian labor migrants is their high level of education and professional experience: 37\% of all labor migrants have complete higher education, $41 \%$ have secondary or vocational education (Ahenstvo OON z pytan mihratsii, 2016), although the dominant types of economic activity among Ukrainian labor mit grants remains construction, the most common among man-ages, and home-grooming, which prevails among women. It is estimated that about one quarter of all migrants working abroad have unregulated status and type of activity that does not meet their educational and intellectual level.

A separate solution should be the outflow of "brain drain" scientists who are left or willing to leave the country because of financial insecurity, social insecurity and insecurity, housing problems, lack of infrastructure, scientific equipment and reagents for conducting research, mobility restrictions, the lack of "social lifts", opportunities for career growth (Zhabin, Isakova, \& Skorokhod, 2018).

Formation of migration law has been taking place for a long time. The basic legal acts have been adopted. The main one is the Constitution of Ukraine. According to Article 26 of the Constitution of Ukraine, foreigners and stateless persons who are legally in Ukraine enjoy the same rights and freedoms as well as carry the same obligations as citizens of Ukraine, with the exception of, established by the Constitution, laws or international agreements of Ukraine. Asylum may be granted to foreigners and stateless persons in the manner prescribed by law. In accordance with Article 33, anyone who is on a permanent basis in Ukraine is guaranteed freedom of movement, free choice of place of residence, the right to freely leave the territory of Ukraine and at any time return to Ukraine, with the exception of restrictions established by law (Verkhovna Rada Ukrainy, 1996).

But despite the numerous legislative acts (Verkhovna Rada Ukrainy, 2011, 2012, 2016), the migration processes of Ukraine's population remain insufficiently regulated in social and labor relations and do not meet the current challenges of socio-economic and demographic development of the country. For example, almost unregulated contractual relations with migrant countries regard the provision of pensions to our citizens, who work outside the country but will receive pensions in Ukraine.

According to the generally accepted classification of the UN International Migration, five of its main varieties are determined:

1. foreigners coming to the country for study;

2. migrants coming to work;

3. migrants coming to join or create new families;

4. migrants arriving for a permanent settlement;

5. foreigners who are admitted to the country for humanitarian reasons (refugees, asylum seekers etc.) (Judina, 2006).

But most of the existing classifications only reflect a certain aspect of migration (for example, duration of legal status of migrants etc.) or apply different criteria for one classification. However, there is currently no single classification, as a migrant can move from one category to another, and its legal status defines both internal and in- 
ternational law. In addition, migratory movements have at the same time not only one, but several characteristics, their division is not unambiguous and final, certain types of resettlements coincide, and the participants, having changed their place of residence only once, can be subjects of the territorial changes of different types. Recently, the meaning of the term "migration" has changed. Salt (2001) notes that it depends on random selection and has a specific content for a certain period of time.

Migration of internally displaced persons, which arose as a result of hostilities in the East of the country, is a significant problem for Ukraine today. According to the latest data from the departments of social protection of the population, the number of internally displaced persons in Ukraine today is $1.6 \mathrm{mln}$ people or almost $1.3 \mathrm{mln}$ families. But information coming from various official sources, and sometimes from the same source, is significantly different or contradictory. In any case, Ukraine has a leading place in the number of internally displaced people in the world and ranked first in Europe and is among the leaders in the world) (Global internal displacement database, 2018).

Thus, the main problems of the uncontrolled migration of the population regarding the reproduction and development of human capital are:

- the significant decrease in the population, with the overwhelming majority of those leaving the country, is in childbearing and working age, has a sufficient educational and professional level. Thus, the labor market is almost not updated by young skilled personnel, the system of continuity of experience is not created, and the future of the country becomes doomed to reducing, reducing the reproduction of the population, its further aging and deteriorating the quality of human capital;

- the intensifying demographic deformations that increase the problem of retirement provision, given that most of the wage earners do not make contributions to the Pension Fund, and returning to their old age in Ukraine are also claiming a pension. Already in 2010 there was a demographic pit that deteriorated all these years. According to the World Bank, Ukraine is in the first 20 countries with a dying population. The worst thing about the country's economic development is the fact that in the last decade the working-age population has been decreasing. Today, Ukraine, in terms of the population over the age of 60 , is among the thirty of the oldest states, occupying 25-26 places in the world ranking by this indicator (Svetlakova, 2017). Consequently, modern depopulation of the population, according to the demographic forecast of specialists, after $4-5$ years, will lead to a reduction of labor resources by $7 \mathrm{mln}$ people, which may have a catastrophic impact on the national economy and the processes of development of society;

- the deepening of social problems associated with the destruction of the family's institute, which in the future will lead to and has already led to a significant number of problems in the future in the formation of the personality of children and adolescents, but so far our marital statistics do not have accurate information how many families have already broken up because of the lack of many years one of the spouses, not to mention predicting their quantity in the future;

- the reducing prestige of Ukrainian education, which in turn leads to an increase in the outflow of youth abroad, and according to the "closed circle" above the above-mentioned problems. After all, only in countries, that implement innovative-technological type of development, knowledge becomes a domestic non-material asset, affect the growth of production volumes, improve the quality of products and services, ensure the competitiveness of the country and accelerate social progress (Heiets, 2015);

- the deterioration of the quality of the human capital of the country, gives the significant outflow of the intellectual and working elite (scientists, educators, doctors, IT specialists, engineers etc).

- Everyone understands that it is impossible to stop labor migration, but it is necessary to build an effective migration policy, that would allow maintaining sufficient intellectual, educational, spiritual and moral sufficient potential for solving the problems of social and labor relations as one of the important directions of the development of the economy of their country.

To draw the conclusion, it should be emphasized, that the main task of the effective regulation of the social and labor sphere should be the creation of satisfactory economic conditions for the sustainable and expanded reproduction of the combined labor force in accordance with the pros and cons of the country and each region of it, improvement of the forecasting methodology the labor market, taking into account regional development 
programs of the branches of the economy, and a new adequate mechanism for identifying the needs for training skilled workers by state order.

To regulate the labor market, the main problem is to be solved - general improvement of the economic situation and investment capital activity, which will allow increasing the number of workplaces and the need for labor. An urgent need for higher incomes and an increase in the general welfare of the population should be an increase in labor productivity, because today, according to the Ministry of Economic Development and Trade, one Ukrainian worker produces goods and services for only UAH 120 thousand a year, while the American - by 100 thousand dollars (Chyrva, 2016).

To solve the identified problems of social and labor relations as one of the important directions of economic development it is necessary:

- to improve the system of state and regional regulation of social and labor relations, that would correspond to the existing market relations, sustainable economic development of the country, taking into account the economic interests of all participants in the social and labor relations in society, would provide decent living conditions for workers through collective- contractual regulation of conditions and wages, employment and other areas included in the sphere of social and labor relations;

- to expand the requirements for the reformation of social and labor relations in the country, taking into account the international social and labor standards in the key areas of ensuring the employment of the population, decent wages and incentives, guarantees for the creation of normal and safe working conditions, the development of a system of professional risk insurance on strategic principles;

- to intensify indirect methods of increasing real wages by introducing a non-taxable minimum of incomes of citizens in the amount of the subsistence minimum for able-bodied persons and increasing the amount of income subject to indexation; to reduce the misbalance between the development of the labor market and the market of educational services, which leads to overestimation of the labor market by specialists from individual professions, while a shortage of skilled workers.

- to substantiate the necessity of transition to an active employment policy as one of the directions for improving the regulation of social and labor relations for which:

- to provide in the programs of restructuring of industries and individual enterprises priority measures to promote employment in regions where there is tension in the labor market, as well as in cities and regions with a monoeconomic structure of production where there is a high level of unemployment;

- to create conditions for increasing the territorial mobility of the population in order to redistribute the workforce between the labor-insufficient and labor-intensive regions;

- to form state and regional job vacancies for the unemployed, taking into account the possibility of providing affordable or temporary housing as one of the main obstacles to domestic migration;

- to create conditions for the employment of non-competitive groups of the population for the reserved, vacant and newly created jobs; to update the mechanisms of granting subsidies to employers by simplifying the procedure for receiving them;

- to develop a methodology for forecasting the needs of the economy in the workforce by types of economic activities and professions, for coordination between state, local government and enterprises in terms of training;

- to introduce mechanisms for stimulating job creation for certain socio-demographic groups (young people, women, the disabled, people before retirement age) and to develop measures to create conditions for expanding the rural population's employment;

- to reduce the burden on the unemployed, it is necessary to improve the conditions for the functioning of small and medium-sized businesses, and to intensify self-employment of the population;

- to develop a social partnership between employers and employees in order to guarantee decent wages, sufficient for the reproduction of labor resources, creation of safe working conditions and provision of grounds for increase of productivity;

- to create conditions for motivating employers to increase investment in vocational education and training (introduction of tax incentives for enterprises investing in education development) and improve the training of unemployed people in the regional broadcasting of enterprises and employers;

- to reduce the imbalance between the development of the labor market and the market of educational services, 
which leads to an over-saturation of the labor market by specialists from individual professions while simultaneously deficits of skilled workers;

- to create conditions for attracting the able-bodied population to legal labor activity and increase the responsibility for its non-compliance;

- to preserve and strengthen the health of the population, to ensure social justice and constitutional rights of citizens to health care, it is necessary to create conditions for improvement of healthcare activities as one of the main directions of development of the country at the expense of improving the health of all segments of the population, reduction of morbidity, mortality, disability, prolongation of active longevity and life expectancy.

\section{CONCLUSION}

The definition of these measures of state and local regulation is due to the peculiarities of the domestic labor market: an unfavorable demographic situation; low quality of the national labor force; weak mobility of labor; inefficient employment of the population; the existence of a significant informal sector of the economy; a small percentage of employed in small businesses; the situation in the countryside.

We consider that it is necessary to strengthen state and regional regulation of social and labor relations with the aim of improving the economy and activating the competitive-market forces, creating conditions for attracting investment and implementing an active employment policy as one of the areas for improving social and labor relations.

Thus, the complex of proposed measures would improve management of the identified problems of social and labor relations as one of the important directions of the development of the economy and create the preconditions for gradual approximation of national social and labor standards to the international level of Ukraine, and improve the quality of life of its population.

\section{REFERENCES}

1. Ahenstvo OON z pytan mihratsii (2016). Міграція як чинник розвитку в Україні: дослідження фінансових надходжень, пов’язаних з міграцією, та їхнього впливу на розвиток в Україні [Mihratsiia yak chynnyk rozvytku v Ukraini: doslidzhennia finansovykh nadkhodzhen, poviazanykh z mihratsiieiu, ta yikhnoho vplyvu na rozvytok v Ukraini]. Retrieved from http://www.iom.org.ua/sites/default/files/mom_migraciya_yak_chynnyk_rozvytku_v_ukrayini.pdf

2. Apteka (2014). Проект Національної стратегії побудови нової системи охорони здоров’я в Україні на період 2015-2025 pp. [Proekt Natsionalnoi stratehii pobudovy novoi systemy okhorony zdorovia $v$ Ukraini na period 2015-2025 rr.]. Retrieved from www.apteka.ua/article/315522

3. Brych, V. (2003). Трансформація ринку праці та проблеми підвищення і життєвого рівня населення: методологія, практика, шляхи вирішення [Трансформація ринку праці та проблеми підвищення і життєвого рівня населення: методологія, практика, шляхи вирішення] (375 р.). Ternopil: Ekonomichna dumka.

4. Chyrva, R. (2016). Українські реалії гідної праці [Ukrainski realii hidnoi pratsi]. Profspilkovi visti, 40, 8-9.

5. Federatsiia profesiinykh spilok Ukrainy (2017). Інформація Депертаменту міжнародних зв'язків апарату [Informatsiia Depertamentu mizhnarodnykh zviazkiv aparatu]. Retrieved from http://www.fpsu.org.ua

6. Federatsiia profesiinykh spilok Ukrainy (2018). Інформація Департаменту захисту соціально-економічних прав апарату [Informatsiia Departamentu zakhystu sotsialno-ekonomichnykh prav aparatu]. Retrieved from http://www.fpsu.org.ua

7. Glavcom (2017). Україна залишається у топ-10 найбідніших країн світу [Ukraina zalyshaietsia u top-10 naibidnishykh krain svitu]. Retrieved from https://glavcom.ua/news/ukrajina-zalishajetsya-u-top-10-naybidnishih-krajin-svitu-bloomberg-401377.html

8. Global internal displacement database (2018). Retrieved from http://www.internal-displacement.org/database

9. Heiets, V. (Ed.) (2015). Інноваційна Україна 2020: національна доповідь [Innovatsiina Ukraina 2020: natsionalna dopovid] (336 p.). Kyiv: NAN Ukrainy. Retrieved from https://cuu.su/ku3/

10. Hrishnova, О. (2009). Економіка праці та соціально-трудові відносини [Ekonomika pratsi ta sotsialno-trudovi vidnosyny] (390 p.). Kyiv: Znannia.

11. Judina, Т. (2006). Социология миграции [Sotsiologyja migratsii] (272 p.). Moskva: Akademicheskij proekt. Retrieved from https://www. twirpx.com/file/214921/

12. Kachan, Y., \& Diakiv, O. (2008). Економіка праці та соціально-трудові відносини [Ekonomika pratsi ta sotsialno-trudovi vidnosyny] (407 p.). Kyiv: Znannia.

13. Libanova, E., \& Palii, О. (2004). Ринок праці та соиіальний захист [Rynok pratsi ta sotsialnyi zakhyst] (491 p.). Kyiv: Osnovy.

14. Minenko, V. (2010). Методологічні підходи до визначення сутності державного регулювання ринку праці і зайнятості населення 
[Metodolohichni pidkhody do vyznachennia sutnosti derzhavnoho rehuliu-vannia rynku pratsi i zainiatosti naselennia]. Ekonomika ta derzhava, 1, 75-78. Retrieved from http://www.economy.in.ua/?op=1\&z=703\&i=17

15. Ministerstvo ekonomichnoho rozvytku i torhivli Ukrainy (2017). Цілі сталого розвитку (ЦСР) в Україні: національна доповідь 2017 [Tsili staloho rozvytku (TsSR) v Ukraini: natsionalna dopovid 2017] (2017). Retrieved from http://un.org.ua/images/SDGs_ NationalReportUA_Web_1.pdf

16. Ministry of social policy (2017). Основні соціальні стандарти, гарантії та показники розвитку України [Osnovni sotsialni standarty, harantii ta pokaznyky rozvytku Ukrainy]. Retrieved from www.msp.gov.ua/

17. Mykhalchenko, H., \& Kobylianskyi, В. (2017). Система охорони здоров’я та праці як складова формування людського капіталу в Україні [Systema okhorony zdorovia ta pratsi yak skladova formuvannia liudskoho kapitalu v Ukraini]. Sotsialno-trudovi vidnosyny: teoriia ta praktyka, 1(13), 89-98. Retrieved from http://ir.kneu.edu.ua/handle/2010/21606

18. Myskevych, Т. (2012). Реформування системи охорони здоров'я в Україні [Reformuvannia systemy okhorony zdorovia v Ukraini]. Retrieved from http://nbuviap.gov.ua/index.php?catid=8\&id=752

19. Osovska, Н., \& Krushelnytska, О. (2010). Управління трудовими ресурсами [Upravlinnia trudovymy resursamy] (224 p.). Kyiv: Kondor.

20. Overchuk, O. (2018). Чверть зайнятого населення змушують працювати напівлегально [Chvert zainiatoho naselennia zmushuiut pratsiuvaty napivlehalno]. Profspilkovi visti, 27-28(957-958), 4.

21. Petiukh, V. (1999). Ринок праці [Rynok pratsi] (288 p). Kyiv: KNEU. Retrieved from https://cuu.su/jH7/

22. Profspilkovi visti (2018). Від зарплати до зарплати [Vid zarplaty do zarplaty]. Profspilkovi visti, 3(933), 8-9. Retrieved from http://www. psv.org.ua/arts/Tema/view-3943.html

23. RBK-Ukraina (2017). Украина попала в категорию самых бедных стран [Ukraina popala v kategoryju samyh bednyh stran]. Retrieved from http://www.rbc.ua/rus/news/economic

24. Reinis Fischer (2017). What's minimum wage in European Union. Retrieved from https://www.reinisfischer.com/whats-minimum-wageeuropean-union-2017

25. Salt, J. (2001). The Business of International Migration. (pp. 80-108). In Siddique M. (Eds.). International migration into the 21st century: essays in honour of Reginald Appleyard. Cheltenham: Edward Elgar.

26. Shafranskyi, V. (Ed.) (2016). Щорічна доповідь про стан здоров’я населення України, санітарно-епідемічну ситуацію та результати діяльності системи охорони здоров'я України. 2015 рік [Shchorichna dopovid pro stan zdorovia naselennia Ukrainy, sanitarnoepidemichnu sytuatsiiu ta rezultaty diialnosti systemy okhorony zdorovia Ukrainy. 2015 rik] (452 p.). Kyiv: MOZ Ukrainy, DU «UISD MOZ Ukrainy». Retrieved from https://cuu.su/jIm/

27. State statistics service of Ukraine (2018). Заборгованість із виплати заробітної плати [Zaborhovanist iz vyplaty zarobitnoi platy]. Retrieved from http://www.ukrstat.gov.ua/operativ/operativ2017/gdn/zvz/zvz_18_u.htm

28. State statistics service of Ukraine (2018). Рівень безробіття у 2017 p. [Riven bezrobittia $u$ 2017 r.]. Retrieved from http://www.ukrstat.gov.ua/

29. State statistics service of ukraine (n.d.). Retrieved from http://www.ukrstat.gov.ua

30. Svetlakova, А. (2017). Демографическая пропасть: нас уже 38 миллионов [Demograficheskaja propast: nas uzhe 38 millionov]. Arhumenty i fakty, 1-2, 5-6. Retrieved from http://www.aif.ua/society/social/demograficheskaya_propast_nas_uzhe_38_millionov

31. Verkhovna Rada Ukrainy (1996). Конституція України від 28 червня 1996 p. [Konstytutsiia Ukrainy vid 28 chervnia 1996 r.]. Retrieved from https://zakon.rada.gov.ua/laws/show/254\%D0\%BA/96-\%D0\%B2\%D1\%80

32. Verkhovna Rada Ukrainy (2011). Концепція державної міграційної політики [Kontseptsiia derzhavnoi mihratsiinoi polityky]. Retrieved from http://zakon.rada.gov.ua/laws/show/622/2011

33. Verkhovna Rada Ukrainy (2012). Закон України «Про імміграцію» [Zakon Ukrainy “Pro immihratsiiu”]. Retrieved from http://zakon2. rada.gov.ua/laws/show/2491-14

34. Verkhovna Rada Ukrainy (2016). Про біженців та осіб, які потребують додаткового або тимчасового захисту [Pro bizhentsiv ta osib, yaki potrebuiut dodatkovoho abo tymchasovoho zakhystu]. Retrieved from http://zakon.rada.gov.ua/laws/show/3671-17

35. Vidomosti Verkhovnoi Rady Ukrainy (2013). Закон України «Про зайнятість населення» [Zakon Ukrainy «Pro zainiatist naselennia»]. Retrieved from https://zakon.rada.gov.ua/laws/show/5067-17

36. WageIndicator (2018). Salary checks - world wide wage comparison. Retrieved from https://wageindicator.org/

37. World health organization (2016). World health statistics 2016: monitoring health for the SDGs. Retrieved from www.who.int/gho/publications/world_health_statistics/2016

38. Zhabin, S., Isakova, N., \& Skorokhod, O. (2018). Аналіз проблем молодих вчених України та рекомендації щодо їхнього вирішення [Analiz problem molodykh vchenykh Ukrainy ta rekomendatsii shchodo yikhnoho vyrishennia]. Retrieved from http://aei.org.ua/1271/ 